\title{
BREAKING STRENGTH BENANG PA MULTIFILAMEN 210D/6 PADA PENYIMPANAN DI RUANG TERBUKA
}

\author{
Mokhamad Dahri Iskandar') dan Andhika Prima Prasetyo ${ }^{2)}$ \\ 1) Dosen pada Fakultas Perikanan dan IImu Kelautan-Institut Pertanian Bogor, Bogor \\ 2) Peneliti pada Pusat Riset Perikanan Tangkap, Ancol-Jakarta \\ Teregistrasi I tanggal: 5 Januari 2010; Diterima setelah perbaikan tanggal: 19 Maret 2010; \\ Disetujui terbit tanggal: 30 Maret 2010
}

\begin{abstract}
ABSTRAK
Penelitian ini bertujuan untuk mengkuantifikasikan pengaruh lama penyimpanan dan pengaruh perendaman dengan cairan berupa solar, oli, dan ter terhadap penurunan nilai kekuatan putus benang polyamide $210 \mathrm{D} / 6$. Hasil penelitian ini menunjukan bahwa kekuatan putus benang jaring semakin menurun setelah mengalami penyimpanan di ruang terbuka selama satu bulan (bulan ke satu) menjadi 5,8657 kgf dari 7,2903 kgf pada awal penyimpanan (bulan ke nol). Penurunan tersebut terus berlanjut sampai bulan keenam. Hasil analisis ragam (ANOVA) dengan taraf uji 5\% ( $\alpha=5 \%)$ menunjukan bahwa lama penyimpanan secara nyata berpengaruh terhadap nilai kekuatan putus (breaking strength) benang polyamide pada ruang terbuka $(P<0,05)$. Kekuatan putus benang Polyamide yang direndam pada cairan perendam berupa oli, solar, dan ter secara keseluruhan mengalami penurunan. Penurunan kekuatan putus terbesar dialami oleh benang yang direndam dengan solar dengan derajat penurunan kekuatan putus mencapai $30 \%$. Hasil analisis ragam (ANOVA) dengan taraf uji $5 \%(\alpha=5 \%)$ menunjukan bahwa cairan perendam secara signifikan berpengaruh terhadap kekuatan putus (breaking strength) benang polyamide $(P<0,05)$. Hasil uji lanjutan BNT menunjukan bahwa nilai kekuatan putus benang polyamide yang diberi pelakuan cairan perendam solar, oli, dan ter berbeda nyata terhadap benang kontrol $(P<0,05)$.
\end{abstract}

KATAKUNCl: $\quad$ breaking strength, benang, polyamide, penyimpanan

ABSTRACT: $\quad$ Breaking strength of PA multifilament 210/D/6 twine in the out door storage. By: Mokhamad Dahri Iskandar and Andhika Prima Prasetyo

The objective of this experiment was to quantify the effect of storage duration and immersed liquid such as diesel fuel, lubricant and tar on the breaking strength of polyamide of $210 \mathrm{D} / 6$. Results of experiment revealed that breaking strength of twine decrease after first month out door storage to be $5,8657 \mathrm{kgf}$ from 7,2903 kgf in begining of storage. Decreasing of twine continued until sixth month of storage. Analyses of variances of $5 \%$ significance level indicated that length duration of storage for polyamide twine significantly different to the breaking strength. Breaking strength of polyamide twine which immersed in the lubricant, fuel diesel, and tar generally decreased. The biggest reduction of breaking strength occurred for twine immersed in the fuel diesel with reduction level until $30 \%$. Analyses of variances of $5 \%$ significance level indicated that immersed liquid significantly affected breaking strength of polyamide twine. Post Hoc test of $L S D$ also indicated that breaking strength of polyamide twine significantly different $(P<0,05)$ between lubricant, fuel diesel, and tar toward control twine

KEYWORDS: $\quad$ breaking strength, polyamide, twine, storage 


\section{PENDAHULUAN}

Benang polyamide merupakan salah satu jenis benang yang umum digunakan di bidang perikanan (Klust, 1983; Nielsen \& Jhonson, 1992 vide Al-Oufi et al., 2004). Menurut Molin (1959) vide Thomas \& Hridayathan (2006) serat polyamide memiliki kelemahan dalam penggunaannya di bidang perikanan, yaitu memiliki sensitifitas yang relatif tinggi terhadap sinar ultraviolet. Kekuatan putus (breaking strength) pada umumnya digunakan untuk mengukur ketahanan suatu serat sintetis (Egerton \& Shah, 1968 vide Thomas \& Hridayathan, 2006). Semakin cepat penurunan kekuatan putus, maka akan meningkatkan biaya untuk perbaikan dan pembelian. Sehingga sangat terkait dengan kelanjutan usaha (Thomas \& Hridayathan, 2006). Weathering (pencuacaan) merupakan salah satu faktor yang mempengaruhi penurunan kekuatan putus benang polyamide. Faktor cuaca yang paling dominan adalah radiasi matahari (Klust, 1983).

Pada saat operasi penangkapan ikan alat tangkap berbahan benang polyamide seperti gillnet diletakan pada udara terbuka di atas perahu. Pada saat tertentu seringkali jaring tersebut terkena tumpahan ter, oli, maupun bahan lainnya. Bahan-bahan tersebut adakalanya tidak dibersihkan karena sebagian nelayan mempunyai kepercayaan bahwa bahanbahan seperti ter maupun oli mempunyai fungsi untuk mengawetkan jaring. Namun secara ilmiah, hal ini perlu dilakukan pembuktian.

Nelayan di berbagai lokasi di Indonesia juga mempunyai kebiasaan untuk meletakan jaring yang telah digunakan untuk waktu yang cukup lama tanpa adanya pelindung di ruang udara terbuka. Klust (1983) mengatakan bahwa jaring yang dijemur secara terusmenerus di udara terbuka akan mengalami penurunan kekuatan putus (breaking strength) karena terkena sinar matahari. Derajat penurunan kekuatan putus benang jaring akibat penyimpanan di ruang terbuka sangat tergantung pada jenis benang dan diameternya (Al Qufi et al., 2004). Di Indonesia penelitian mengenai kekuatan putus benang jaring akibat penyimpanan di ruang terbuka belum pernah dilakukan. Adapun penelitian mengenai pengaruh perendaman telah dilakukan oleh Sukma (2003), hasil penelitiannya menunjukan kekuatan putus benang polyamide multifilamen $210 \mathrm{D} / 9$ setelah direndam di dalam oli, minyak tanah, dan solar memiliki kekuatan putus yang meningkat. Tetapi ketika direndam dengan bensin benang mengalami penurunan kekuatan putus. Namun penelitian tersebut tidak dilakukan dengan mempertimbangkan faktor cuaca, karena benang polyamide hanya direndam. Untuk itu penelitian ini mencoba untuk menentukan kekuatan putus benang jaring polyamide $\mathrm{D} 6 / 210$ yang mengalami penyimpanan di ruang terbuka.

\section{BAHAN DAN METODE}

Penelitian ini dilaksanakan pada bulan Juli 2008Januari 2009. Penelitian ini dilakukan di Stasiun Klimatologi Darmaga, Bogor dan Bagian Teknologi Alat Penangkapan Ikan, Departemen Pemanfaatan Sumber Daya Perikanan, Fakultas Perikanan dan IImu Kelautan, Institut Pertanian Bogor. Bahan yang digunakan pada penelitian ini meliputi benang polyamide multifilamen $210 \mathrm{D} / 6$ merk double fish brand sepanjang $128 \mathrm{~m}$, aspal merk CELL $2 \mathrm{~L}$, thiner merk super quality $2 \mathrm{~L}$, solar merk pertamina $2 \mathrm{~L}$, dan oli merk MESRAN Super SAE 20W-50 2 L. Metode penelitian ini adalah experimental laboratory (penelitian pada skala laboratorium). Pengumpulan data kekuatan putus dan unsur cuaca dilakukan setiap bulan. Panjang satu contoh benang $20 \mathrm{~cm}$. Sebelum diletakkan di ruang penyimpanan benang terlebih dahulu direndam pada cairan solar, oli, dan ter selama 48 jam agar cairan menyerap ke dalam serat. Setelah direndam, benang dipasangkan pada panel yang terbuat dari kayu dengan ukuran PxL $(200 \times 50 \mathrm{~cm})$ (Gambar 1). Selanjutnya panel tersebut diletakkan di ruang terbuka tanpa pelindung. Setiap bulan benang diuji kekuatan putusnya dengan mesin breaking strength tester merek Shimadzu AUTOGRAPHAGS$D$ series. Data unsur-unsur cuaca (intensitas radiasi matahari, curah hujan, suhu, kelembaban, dan lainlain) selama periode penelitian diperoleh dari pencatatan yang dilakukan oleh Stasiun Klimatologi Darmaga Bogor. Rancangan percobaan yang digunakan untuk mengamati pengaruh lama penyimpanan terhadap kekuatan putus benang polyamide $210 \mathrm{D} / 6$ tanpa perlakuan adalah rancangan acak lengkap sedangkan untuk mengamati pengaruh faktor lama penyimpanan dengan cairan perendam digunaklan rancangan acak faktorial dengan taraf uji $(\alpha=0,05)$. Setiap perlakuan dilakukan 10 kali ulangan. 


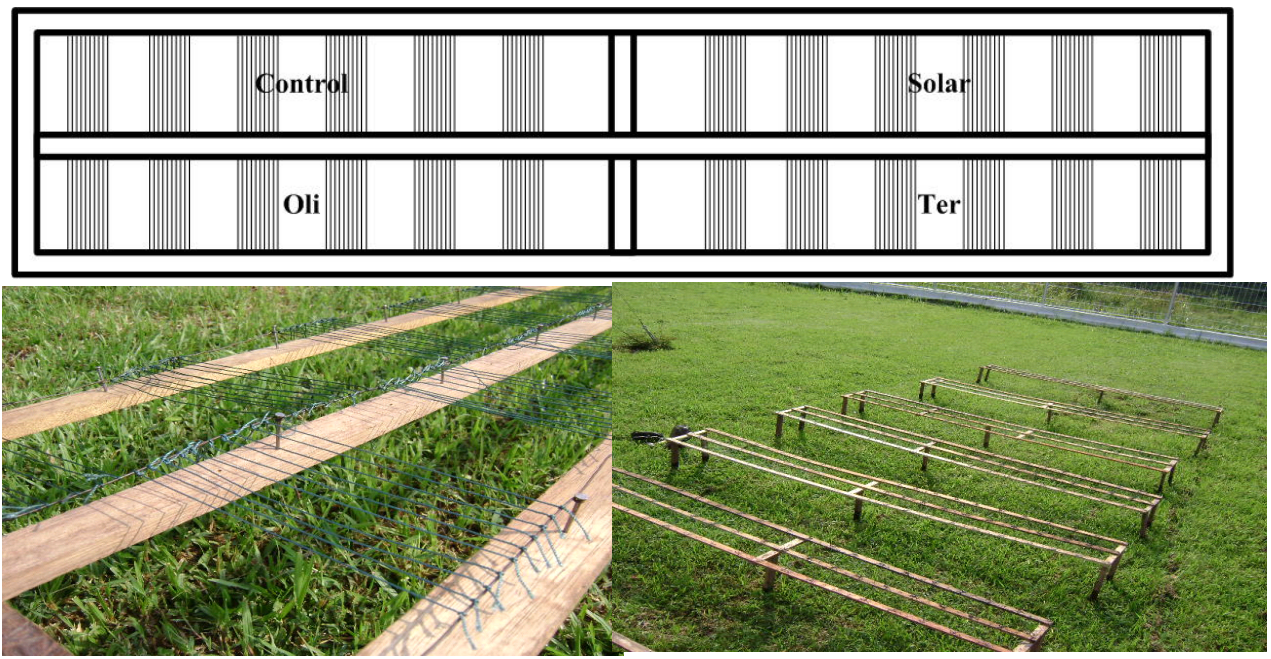

Gambar 1.

Pemasangan benang pada panel.

Figure 1. Setting of twine at panel.

\section{HASIL DAN BAHASAN}

\section{Kondisi Umum Cuaca Selama Penelitian}

Nilai intensitas radiasi matahari tertinggi terjadi pada bulan September 2008 yaitu $9.526 \mathrm{cal} / \mathrm{cm}^{2}$. Adapun nilai intensitas radiasi matahari terendah terjadi pada bulan Januari 2009 yaitu $6.299 \mathrm{cal} / \mathrm{cm}^{2}$. Nilai curah hujan pada awal penelitian yaitu pada bulan Mei $277 \mathrm{~mm}$. Nilai ini berasal dari penjumlahan nilai curah hujan selama satu bulan. Nilai curah hujan tertinggi terjadi pada bulan Nopember 2008 yaitu 509 $\mathrm{mm}$. Adapun nilai curah hujan terendah terjadi pada bulan Juni 2008 yaitu $171,5 \mathrm{~mm}$. Suhu rata-rata yang terjadi selama periode bulan Mei 2008-Januari 2009 berkisar antara $25-25,9^{\circ} \mathrm{C}$, suhu rata-rata ini diperoleh dari rata-rata suhu harian selama satu bulan. Kondisi kelembaban selama periode bulan Mei 2008-Januari 2009 berfluktuatif. Kelembaban rata-rata lokasi penelitian berkisar antara $77-88 \%$. Secara lebih rinci, kondisi cuaca yang terjadi selama penelitian disajikan pada Gambar 2.
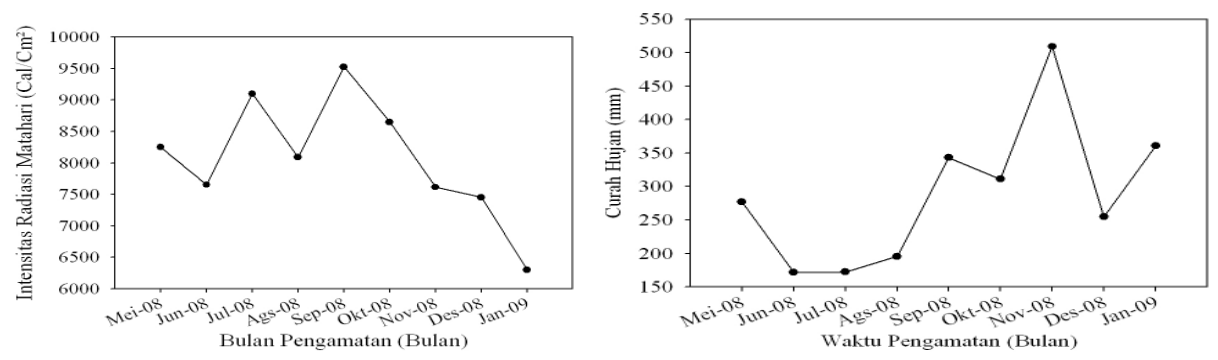

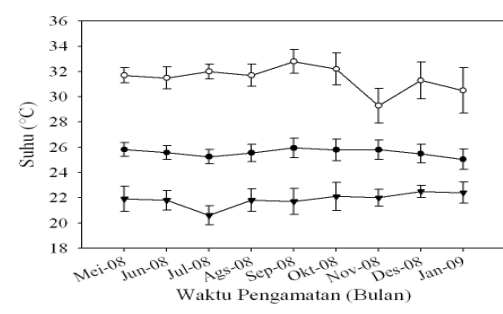

Gambar 2. Figure 2.

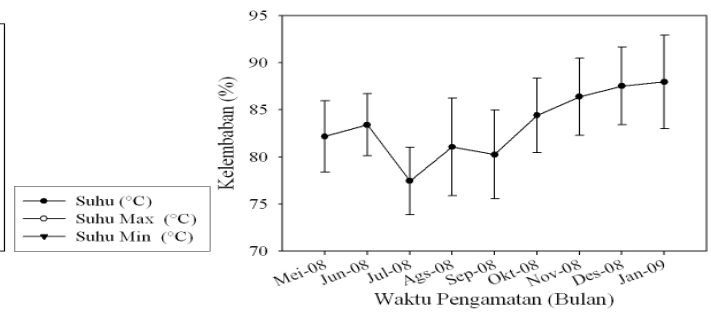

Kondisi cuaca selama penelitian.

Weather condition during the experiment.

Sumber/Sources: Stasiun Klimatologi Darmaga Bogor (2009) Keterangan/Remarks: a) total intensitas radiasi matahari; b) total curah hujan; c) suhu rata-rata, suhu maksimum, dan suhu minimum; d) ratarata kelembaban 


\section{Pengaruh Lama Penyimpanan terhadap Kekuatan Putus Benang Polyamide}

Kekuatan putus benang polyamide kontrol pada saat bulan ke nol (awal penyimpanan) 7,2903 kgf.
Kekuatan putus benang jaring semakin menurun setelah mengalami penyimpanan di ruang terbuka selama satu bulan (bulan kesatu) menjadi 5,8657. Penurunan tersebut terus berlanjut sampai bulan keenam (Gambar 3).

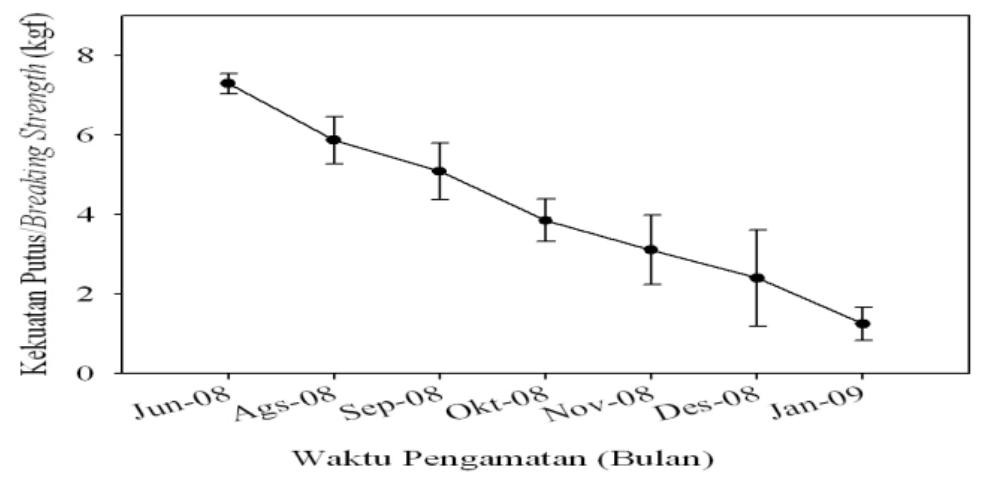

Gambar 3. Kekuatan putus benang polyamide selama penelitian.

Figure 3. Breaking strength of polyamide twine during experiment.

Hasil analisis ragam (ANOVA) dengan taraf uji 5\% $(\alpha=5 \%$ ) untuk benang polyamide menunjukan bahwa lama penyimpanan secara nyata berpengaruh terhadap nilai kekuatan putus (breaking strength) benang polyamide pada ruang terbuka $(P<0,05)$. Sehingga dapat dikatakan kekuatan putus benang polyamide semakin menurun per satuan waktu. Hasil uji lanjutan BNT menunjukan bahwa nilai kekuatan putus benang polyamide pada bulan 1, 2, 3, 4, 5, dan 6 berbeda nyata dengan kekuatan putus benang pada bulan nol $(\mathrm{P}<0,05)$.

Hasil analisis regresi antara kekuatan putus $(\mathrm{Y})$ benang polyamide terhadap lama penyimpanan $(X)$ diperoleh persamaan:

$$
\begin{aligned}
& Y=-0,966 X+7,017 \\
& r=100 \% ; R^{2}=99 \%
\end{aligned}
$$

Persamaan tersebut dapat diinterpretasikan bahwa setiap penambahan satu bulan waktu penyimpanan maka kekuatan benang polyamide 210 D/6 akan berkurang kekuatan putusnya $0,97 \mathrm{kgf}$.

Semakin lama penyimpanan, maka kekuatan putus benang akan semakin berkurang. Rendahnya nilai kekuatan putus benang jaring yang disimpan di ruang terbuka disebabkan oleh adanya pengaruh faktor lingkungan (environmental factor), berupa radiasi matahari, curah hujan, suhu, kelembaban, polusi, dan sebagainya. Pengaruh-pengaruh tersebut dikenal dengan istilah weathering. Faktor luar yang paling mempengaruhi ketahanan serat adalah radiasi matahari (Klust, 1983). Serat yang tidak terlindung dari sinar matahari langsung akan mengalami kerusakan berupa putusnya stuktur molekul dari polimer, yang akhirnya serat tersebut akan kehilangan kekuatan (strength), kemuluran (extensibility), kekuatan terhadap waktu (general durability), dan bentuk (Achhmmer et al., 1953 vide Thomas \& Hridayathan, 2006).

Untuk mengurangi efek kerusakan serat sintetis akibat pengaruh langsung dari radiasi matahari, maka diperlukan penanganan yang tepat. Sebagai contoh penanganan yang tepat adalah menyimpan alat tangkap pada ruang terlindung untuk mengurangi efek kerusakan serat sintetis akibat pengaruh langsung dari radiasi matahari (Saravanan, 2007; Warenzeichenverband, 1959 videAl-Oufi et al., 2004). Penjemuran alat tangkap di bawah sinar matahari secara langsung tersebut menjadi kebiasaan nelayan sejak dahulu. Penjemuran tidak hanya dilakukan setelah alat tangkap dioperasikan, tetapi juga dilakukan saat alat tangkap tersebut tidak digunakan. Tingkat pendidikan nelayan pada umumnya rendah membuat pengetahuan nelayan mengenai ketahanan serat sintetis terhadap pelapukan terbatas, sehingga nelayan berpikir bahwa penjemuran akan meningkatkan umur pemakaian alat tangkap (Al-Oufi et al., 2000 vide Al-Oufi et al., 2004). Dahm (1992) vide Al-Oufi et al. (2004) menambahkan bahwa kerusakan akibat radiasi ultaviolet berpengaruh terhadap pengurangan umur operasi dan menurunkan kemampuan tangkap (catchability) alat tangkap yang pada akhirnya menurunkan pendapatan. 


\section{Pengaruh Cairan Perendam terhadap Kekuatan} Putus Benang Polyamide

Secara umum, benang polyamide yang telah mengalami perlakuan berupa perendaman mengalami penurunan kekuatan putus pada satu bulan setelah penyimpanan kecuali pada benang polyamide yang direndam dengan menggunakan ter. Kekuatan putus benang yang direndam dengan menggunakan ter pada awal penyimpanan (bulan ke nol) 5,1280 kgf. Setelah penyimpanan selama satu bulan (bulan kesatu) kekuatan putus benang tersebut bertambah menjadi 5,9054 kgf. Penurunan kekuatan putus terbesar dialami oleh benang polyamide yang direndam dengan menggunakan solar mengalami penurunan kekuatan putus sekitar 30\% (Gambar 4).

Hasil analisis ragam (ANOVA) dengan taraf uji 5\% $(\alpha=5 \%)$ untuk benang polyamide menunjukan bahwa cairan perendam berpengaruh terhadap nilai kekuatan putus (breaking strength) benang polyamide $(P<0,05)$. Kekuatan putus benang polyamide semakin menurun pada perlakuan cairan perendam per satuan waktu. Hasil uji lanjutan BNT menunjukan bahwa nilai kekuatan putus benang polyamide yang diberi pelakuan cairan perendam solar, oli, dan ter berbeda nyata terhadap benang kontrol $(P<0,05)$.

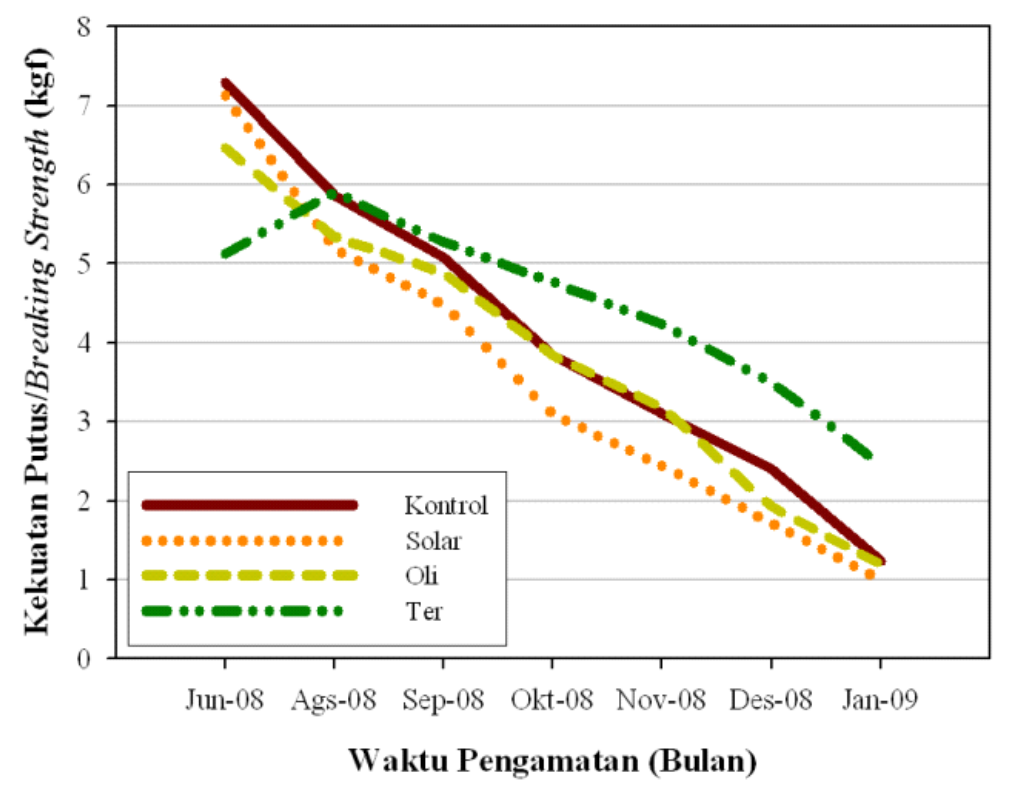

Gambar 4. Kekuatan putus benang polyamide selama penelitian.

Figure 4. Breaking strength of polyamide twine during experiment.

Hubungan antara kekuatan putus benang polyamide yang diberi perlakuan berupa perendaman pada beberapa cairan dengan lama waktu penyimpanan digambarkan dengan persamaan regresi sebagai berikut:

1. Benang polyamide yang direndam dengan oli.

$$
\begin{aligned}
& Y=-0,868 X+6,440 \\
& r=100 \% ; R^{2}=99 \%
\end{aligned}
$$

2. Benang polyamide yang direndam dengan ter.

$$
Y=-0,493 X+5,949
$$$$
r=91 \% ; R^{2}=83 \%
$$

3. Benang polyamide yang direndam dengan solar.

$$
\begin{aligned}
& Y=-0,978 X+6,516 \\
& r=98 \% ; R^{2}=97 \%
\end{aligned}
$$

4. Benang polyamide yang direndam dengan solar.

$$
\begin{aligned}
& Y=-0,966 X+7,017 \\
& r=100 \% ; R^{2}=99 \%
\end{aligned}
$$

Berdasarkan pada persamaan regresi tersebut maka benang polyamide yang sebelumnya direndam pada solar paling sensitif terhadap pengaruh penyimpanan di ruang terbuka, di mana setiap bertambahnya satu bulan penyimpanan akan menurunkan kekuatan putus $0,978 \mathrm{kgf}$. Adapun benang polyamide yang sebelumnya direndam pada 
ter menunjukan sensitifitas yang lebih rendah terhadap pengaruh lokasi penyimpanan, di mana setiap bertambahnya satu bulan penyimpanan akan menurunkan kekuatan putus 0,493 kgf. Sehingga perendaman benang polyamide pada cairan ter akan memberikan efek ketahanan yang lebih baik dibandingan solar dan oli untuk penyimpanan di ruang terbuka. Namun kekuatan putus untuk benang polyamide yang sebelumnya direndam pada ter pada bulan pertama (bulan kesatu) lebih tinggi dibanding dengan awal penelitian (bulan ke nol), hal ini disebabkan setelah direndam pada ter benang dalam kondisi basah. Setelah dilakukan penjemuran benang berangsur-angsur kering. Kekuatan putus benang dalam kondisi basah lebih rendah dibandingkan kekuatan putus benang dalam kondisi kering (Klust, 1983).

Jika dibandingkan pengaruh cairan perendam (solar, oli, dan ter) terhadap kekuatan putus benang dan jaring polyamide kontrol (tanpa perendam) yang disimpan pada ruang terbuka menunjukan bahwa perendam berupa ter memberikan pengaruh terbaik dalam mengurangi laju kerusakan akibat lama penjemuran. Adapun penurunan kekuatan putus untuk benang dan jaring tanpa perendaman (kontrol) terkait dengan penuaan (ageing) dan pengaruh lingkungan (environmental factors). Persentase perubahan kekuatan putus benang dan jaring polyamide yang sebelumnya direndam pada ter memiliki nilai terendah dibandingkan benang dan jaring dengan perendam lain. Jika dibandingkan antara ter dengan oli, ter bersifat lebih kental dan ikatan antara molekulnya relatif kuat (Giwangkara, 2007). Namun karena titik bekunya tinggi, sehingga ter lebih cepat kering dan melapisi permukaan benang dan jaring dibandingkan dengan oli. Walaupun solar juga mampu untuk mengisi rongga pada serabut benang dan jaring, tetapi karena viskositas solar yang rendah dibandingkan cairan oli dan ter sehingga membuat solar lebih mudah menguap (Giwangkara, 2007). Selain itu solar juga memiliki titik beku yang relatif lebih rendah dibandingkan dengan oli dan ter, sehingga tidak dapat melapisi permukaan benang dan jaring secara sempurna. Penggunaan cairan ter dan oli sama-sama memberikan pengaruh dalam menghambat laju penurunan kekuatan putus, namun ter lebih baik dibandingkan dengan oli. Hal tersebut karena ter memiliki kandungan oli dalam komposisinya di samping mesin dan asphaltenes (Sukirman, 2007).

Perendaman pada solar justru membuat kekuatan benang dan jaring polyamide lebih rendah dibandingkan dengan benang dan jaring kontrol.
Menurut Sukma (2003) hal tersebut diduga terkait dengan nilai specific gravity. Specific gravity solar paling rendah dibandingkan dengan oli dan ter, yaitu berkisar $820-950 \mathrm{~kg} / \mathrm{m}^{3}$ untuk suhu $60^{\circ} \mathrm{F}$ atau $15,56^{\circ} \mathrm{C}$ (Walker, 2007). Dengan demikian keterikatan molekul solar dan molekul serat menjadi lemah. Adapun perendaman pada oli membuat kekuatan benang dan jaring polyamide lebih tinggi dibandingkan dengan benang dan jaring kontrol, namun tetap lebih kecil jika dibandingkan dengan perendaman ter. Hal tersebut diduga karena nilai specific gravity oli lebih besar dari pada solar, namun lebih rendah jika dibandingkan dengan ter, yaitu berkisar $880-940 \mathrm{~kg} /$ $\mathrm{m}^{3}$ untuk suhu $60^{\circ} \mathrm{F}$ atau $15,56^{\circ} \mathrm{C}$ (Walker, 2007), sehingga keterikatan molekul oli dan molekul serat menjadi lebih kuat dibandingkan dengan serat yang direndam pada solar.

Perendaman baik benang maupun jaring polyamide pada cairan ter menunjukan bahwa ter mampu untuk melindungi pengaruh weathering. Hasil penelitian Al-Oufi et al. (2004) menunjukan bahwa untuk jangka waktu tujuh minggu serat sintetis yang diberi perlakuan perendaman pada ter memiliki nilai kekuatan putus lebih baik dibandingkan dengan serat yang tidak diberi perlakuan. Menurut Warenzeichenverband (1959) videAl-Oufi et al. (2004) penggunaan ter untuk serat sintetis tidak hanya meningkatkan ketahanan terhadap radiasi, tetapi juga meningkatkan kekakuan (stiffness), kecepatan tenggelam (sinking speed), ketahanan gesekan (abrasion resistance), dan stabilitas simpul (knot stability). Kelemahan dari penggunaan ter sebagai adalah penambahan bobot dari alat tangkap. Walaupun pun begitu menurut Al-Oufi et al. (2004) perlindungan serat sintesis dari pengaruh radiasi matahari dapat dilakukan dengan memberikan penyerap radiasi (radiation-absorbers) selama dan setelah proses produksi.

\section{KESIMPULAN DAN SARAN}

\section{Kesimpulan}

1. Kekuatan putus benang polyamide mengalami penurunan secara signifikan $(P<0,05)$ dengan semakin bertambahnya waktu penyimpanan di ruang terbuka.

2. Perendaman benang polyamide dengan menggunakan cairan ter menghasilkan nilai kekuatan putus yang lebih baik dibandingkan dengan perendaman dengan menggunakan solar dan oli. 


\section{Saran}

1. Penelitian lanjutan mengenai dampak cairan perendam solar, oli, dan ter terhadap serat sintetis lain, seperti PE maupun serat alami.

2. Penelitian lanjutan mengenai dampak cairan perendam lain, seperti minyak tanah, thiner, dan cairan lumpur terhadap kekuatan putus serat sintetis dan alami.

\section{PERSANTUNAN}

Kegiatan ini menggunakan biaya sendiri, dilaksanakan bersamaan dengan penelitian skripsi mahasiswa di Departemen Pemanfaatan Sumber Daya Perikanan, T. A. 2008. Penulis mengucapkan terima kasih kepada Badan Meteorologi, Klimatologi, dan Geofisika Darmaga Bogor dan Bagian Teknologi Alat Penangkap Ikan, Departemen Pemanfaatan Sumber Daya Perikanan, Fakultas Perikanan dan IImu Kelautan, Institut Pertanian Bogor atas fasilitas dan kontribusi data untuk penelitian ini.

\section{DAFTAR PUSTAKA}

Al-Oufi, H., E. McLean, A. S. Kumar, M. Claereboundt, \& M. Al-Habsi. 2004. The effects of solar radiation upon breaking strength and elongation of fishing nets. Fisheries Research. 66: 115-119.

Giwangkara, Eg. 2007. Cara bikin LPG, Bensin, Minyak Tanah, Solar, dan lain-lain. [terhubung tidak berkala]. http://givangkara.multiply.com/journal/item/ 50. Tanggal 30 Pebruari 2009.
Klust, G. 1983. Bahan Jaring untuk Alat Penangkapan Ikan. Edisi ke-2. (Penterjemah Team BPPI Semarang). Terjemahan dari Netting Materials for Fishing Gear. Semarang. BPPI Semarang. 187 pp.

Sukirman, S. 2007. Beton Aspal Campuran Panas. Jakarta. Yayasan Obor Indonesia. 178 pp.

Thomas, N. S. \& C. Hridayathan. 2006. The effects of natural sunlight on the strength of polyamide 6 multifilament and monofilament fishing net materials. Fisheries Research. 81: 326-330.

Saravanan, D. 2007. UV protection textile materials. AUTEX. 7 (1): 53-62.

Sukma, P. W. 2003. Kekuatan putus benang jaring polyamide (PA) multifilamen $210 \mathrm{D} / 9$ setelah direndam di dalam oli, minyak tanah, solar, dan bensin. Skripsi. Program Studi Pemanfaatan Sumber Daya Perikanan. Fakultas Perikanan dan IImu Kelautan. Institut Pertanian Bogor. Bogor. 30 pp.

Stasiun Klimatologi Darmaga Bogor. 2009. Data Klimatologi Periode Juli 2008-Januari 2009.

Walker, R. 2007. Specific Gravity of Liquids. [terhubung tidak berkala]. http://www.simetric.co.uk/ si_liquids.htm. Tanggal 18 Pebruari 2009. 